\title{
Promoting Process Analysis of New Public Service on China Urban Agglomeration Coordinated Development
}

\author{
Jing $\mathrm{ZHAO}^{1, \mathrm{a}^{*}}$, Jia LIU ${ }^{1, \mathrm{~b}}$ and Xinghua DANG ${ }^{1, \mathrm{c}}$ \\ ${ }^{1}$ School of Economics and Management, Xi'an University of Technology, Xi'an, China \\ azj00000000@126.com, b1439447674@qq.com, 'z28j@hotmail.com
}

Keywords: Urban agglomeration; Coordinated development; New public service; Governance pattern

\begin{abstract}
This paper clarifies the influence of the present system of public administration on the uncoordinated development phenomena of urban agglomeration based on the analysis of the conception of the new public service and China urban agglomeration coord inated development. And this paper provides specific measures to introduce the new public service into China urban agglomeration development. The paper points out that the process of new public service promoting China urban agglomeration coordinated development lies in three aspects: maintaining the public interests; reaffirming the rights of citizens and protecting the public spirit. Furthermore, several suggestions have been stated to insure the application of the new public service to China urban agglomeration coordinated development after analyzing the present situation of China urban agglomeration development.
\end{abstract}

\section{Introduction}

In the process of globalization, the urban agglomeration is a special kind of city space organization, and urban agglomerations make a constantly increasing contribution to the economic growth of China. Urban agglomerations have gradually become the economic growth pole of China [1]. At present, urban agglomeration plans are being made in many cities and provinces of China. Urban agg lomeration is made up of cities with different sizes and they are linked by traffic network in a given area. Urban agglomeration is an inevitable result when urbanization reaches a certain level. But the gap of development among cities and towns in urban agglomeration is widening constantly. The widening gap does harm to the coordinated development of urban agglomeration. So how to promote urban agglomeration coordinated development has already become an important issue in China administration academia. On the basis of the reorganization of relevant literature about urban agglomeration coordinated development, this paper clarifies the uncoordinated development phenomena of urban agglomeration and finds that the present public govemance patterns have facilitated the appearances of these uncoordinated phenomena to a certain extent.

\section{Intension of the new public service and theories of China urban agglomeration coordinated development}

Intension of the new public service. The appearance of "New Public Service" stems from the arguments on the new public management and the old public administration. The new public service is built on work in democratic citizenship, community and civil society, and organizational humanism and discourse theory. The old public administration is always plagued with excessive rules, bound by rigid budget and personnel systems, and preoccupied with control. These traditional bureaucracies are described as ignoring citizens, shunning innovation, and serving their own needs. As a result, a number of highly positive changes have been implemented in the public sector. The new public management is not only the implementation of new techniques but also carries with a new set of values, especially a set of values largely drawn from the private sector [2]. 
Denhardt(2001) concluded by considering the implication s of placing citizen s, citizenship, and the public interests at the forefront of the new public service [3]. The new public service has seven principles [4]:1. Serve, rather than steer; 2 . The public interests is the aim, not the by -product; 3 . Think strategically, act democratically; 4. Serve citizens, not custo mers; 5. Accountability isn't simple; 6. Value people, not just productivity; 7. Value citizen ship and public service above entrepreneurship.

Some Chinese scholars concluded that the most important characteristics of the new public service are these [5]: 1. Repositioning the role of the govemment; 2. Maintaining the public interests; 3. Putting emphasis on respecting citizen's right. Presently, the research on how to use the new public service in China administration governance is very little.

The connotation of urban agglomeration coordinated development. The urban agglomeration coordinated development is a situation of a kind of benign circulation that refers to collaboration, co-operation and promotion among subsystems for total evolvement goal. Therefore, China urban agglomeration coordinated development is the development of cities of any scale, small towns and countryside in the interior of urban agglomeration through mutual linking, mutual promotion and benign interaction, which satisfies the development demands and improves the wealth level of all the communities in the interior of urban agglomeration. So the performance of coordin ated development of Chin a urban agglomeration is the reduction of development $g$ aps among cities with any scale, small towns and countryside in the interior of urban agglomeration. In this paper, the definition of "development gaps" are not the gaps of regional economic level. Presently, there are many researches on "economic development level" in domestic economic circles. The indexes of measuring the gaps of regional economic level are mainly concen trated on GDP per capita or per labor and GNP per capita or per labor, income per capita and consumption per capita. Few researches refer to other social indexes, such as average educated age, sanitation cost per capita and some other researches even develop a systematic indicator system [6]. The "regional development gaps" that should be narrowed do not only refer to economic efficiency but also social equity.

\section{The uncoordinated phenomena of China urban agglomeration and reasons connected with administration}

With reference to the related research, this paper generalizes two aspects of administration phenomena of China urban agg lomeration uncoordinated development. (1)The economic development does not match with social development within urban agglomeration. Social security, medical treatment, technology, literacy, environmental protection have fallen behind with economic growth. The distributions of basic public service among cities or between city and countryside have done negative effect on social equality and have made citizens distrust government. (2) The system of administration presently constraint the development of China urban agglomeration, which has had influence on the inner construction and function of China urban agglomeration and city system and is responsible for market division and restriction of production element flowing.

There are many reasons that could account for the uncoordinated phenomena of China urban agglomeration. As for the uncoordinated phenomena (1) mentioned above, the present governance pattem for China urban agglomeration implied an assumption about "economic reductionism". The market mechanism is overall emphasized, so more attention should be paid to market-oriented values: competition, efficiency and performance for example [7]. The governance pattern makes most of the govemment's expenditure put in infrastructure construction that has direct influence on economic growth. But the basic public service facility in urban agglomeration just gets less support by local govemment. So the insufficient investment on social infrastructure harms the even equalization of basic public service level of urban agglomeration. And the basic public service level is the important factor of region development. As for the uncoordinated phenomena (2) mentioned above, the present govemance pattern for China urban agglomeration is beneficial to the urban sprawl. The existing 
administrative system is unwilling to invest in the border zone of a city based on the local interest. This also hinders the shrinking of regional gap in urban agglomeration and promotes market segmentation.

\section{The process of the new public service promoting China urban agglome ration coordinated development}

The gap of development level is made up of two parts: the gap of economic development and the gap of social development [8]. And according to the an aly sis of the preceding chapter, the $g$ ap of social infrastructure in China urban agglomeration is more serious than the gap of economic growth in China urban agglomeration. The social infrastructure has very strong public beneficial and space spillover effect. It is the important factor of welfare and social feasibility of urban agglomeration. The analysis process that realization of the urban agglomeration coordinated development lies in the following three as pects through in troducing the new public service.

Maintain the public interests. According to the research on public choice, the public interests of urban agglomeration results from a dialogue about shared values, rather than the aggregation of individual self-interests. According to the analysis described above, the present public governance pattems pay more attention to protect individual interests and common interests of organizations in the urban agglomeration, but pay less attention to protect public interests [9].

The present public governance pattem s particularly lay emphasis on the value of market orientation, such as competition, efficiency, performance, etc. And this kind of public govemance patterns have harmed the public interests of urban agglomeration by using market model. In many cases, govemments and government agencies have succeeded in privatizing public functions, holding top executives accountable for performance goals, establishing new processes for measuring productivity and effectiveness, and reengineering departmental systems to reflect a promoted commitment to accountability. These behaviors does harm on the public interests of urban agglomeration, especially paying less attention to social infrastructure development. By introducing the new public service, the public managers help citizens to launch dialogues about shared values. This dialogue process can avoid the lagging of social infrastructure development, and further avoid enlarging the interior development gap of urban agglomeration.

Reaffirm the rights of citizens. The new public management takes citizen as "customer" and the old public administration take citizen as "voter". Both of them make the citizen's be entity fuzzier in the theoretical circles of the present public govemance pattern. So the present public governance pattems threaten to undermine democratic and constitutional values such as fairness, justice, representation, and participation (Terry,1993;1998). But the citizens are just the main body of public life. New public service seeks to encourage more and more people to fulfill their responsibilities as citizen s and encourage government to be especially sen sitive to the voices of citizen s [10].

Introducing the new public service to urban agglomeration development can reaffirm the rights of citizens of urban agglomeration. The trust between citizens and government will be promoted through the dialogue that aims at protecting the rights of citizens, which promotes urban agglomeration coordinated development.

Protect the public spirit from being harmed. Now during the development of China urban agglomeration, the public administration pays more attention to efficiency and performance but less attention to maintain the spirit of fairness and justice. It is very harmful to the public spirit of urban agglomeration. This phenomenon also reduces the people's enthusiasm of participating in public life and reduces the people's trust in the government. As the main body of public life, the citizen should strengthen his own public idea and public spirit only in realistic experience. And without this idea and spirit the citizen is hard to express his own will and his demand for development.

Introducing the new public service the public manager helps citizens to explain and realize public interests clearly, rather than attempt to control or steer society. The actions of public managers will protect the public spirit from being harmed and promote the trust between society personnel of urban 
agglomeration. And through the protection of the public spirit, people will participate in public life positively [11]. All of these transformations can promote the output of urban agglomeration. So introducing the new public service can promote China urban agglomeration coordinated development in three aspects: increasing output, expressing the citizen's demand for development and promoting the trust between society personnel.

\section{Conclusions}

This paper focuses on the application of new public service to China urban agglomeration coord in ated development and the conclu sions are as follows:

1. The present system of public administration of China urban agg lo meration have done harm to the public interests of urban agglomeration, neglected the public service level gap expansion in urban agglomeration and hindered the urb an agglomeration coordinated development.

2. The process of new public service promoting China urban agglomeration coordinated development lies in three aspects: maintaining the public interests; reaffirming the rights of citizen s and protecting the public spirit. New public service promotes the urban agglomeration coordinated development by increasing the social redistribution, promoting social in frastructure development and promoting the basic public service even equalization of urban agglomeration.

\section{Acknowledgment}

This work was supported, in part, by the National Natural Science Found ation of China (Grant No. 71203178), the Science and Technology Program of Shaanxi Province (Grant No. 2013KJXX-37), the Foundation of Shaanxi Educational Committee (Grant No. 14JK1492) and the Shaanxi provincial philos ophy and social science characteristic discipline (Grant No. 107-5X1203).

\section{References}

[1] B.L. Han, R.S. Wang, Y. Tao, H. Gao, Urban population agglomeration in view of complex ecological niche: A case study on Chinese prefecture cities, Ecological Indicators, 47 (2014) 128-136.

[2] A.M. Titu, A.I. Vlad, Quality Indicators in Reference to the Evaluation of the Quality Management of Services in Local Public Admin istration, Procedia Economics and Finance, 16 (2014) 131-140.

[3] L. Deleon, R.B. Denhardt, The Political Theory of Reinvention, Public Administration Review, 60 (2000) 89-97.

[4] R.B. Denhardt, J.V. Denhardt, The New Public Service: Serving Rather Than Steering, Public Administration Review, 60 (2000) 549-559.

[5] J.L. Perry, Democracy and the new public service, The American review of public administration, 37 (2007) 3-16.

[6] A.P. Chen, Reducing China's regional disparities: Is there a growth cost?, China Economic Review, 21 (2010) 2-13.

[7] R.J. Gregory. Social Capital Theory and Administrative Reform: Maintaining Ethical Probity in Public Service, Public Administration Review, 59 (1999) 68-69,73.

[8] M.J. Herreriasa, J. Ordoñez, New evidence on the role of regional clusters and convergence in China (1952-2008), China Economic Review, 23 (2012) 1120-1133.

[9] R. Andrewsa, S. Van de Walle. New Public Management and Citizens' Perceptions of Local Service Efficiency, Responsiveness, Equity and Effectiveness. Public Management Review, 15 (2013) 762-783. 
[10] T. Nam, Suggesting frameworks of citizen-sourcing via Government 2.0, Government Information Quarterly, 29 (2012) 12-20.

[11] O. C. Nicoleta, The Mission of Public Administration In Guaranteeing Citizen's Rights and Freedoms, Procedia - Social and Behavioral Sciences, 81 (2013) 167-170. 